\title{
Pengembangan Alat Ukur Keefektifan Pembelajaran Guru Pendidikan Jasmani Kota Banda Aceh
}

\author{
Boihaqi S.Pd. M.Pd \\ Fakultas Keguruan dan Ilmu Pendidikan, Universitas Serambi Mekkah \\ Email : boihaqi84@gmail.com
}

\begin{abstract}
Abstrak
Tujuan dari penelitian ini adalah untuk mengembangkan alat ukur keefektifan pembelajaran guru pendidikan jasmani pada SMAN Kota Banda Aceh sebagai skala penilaian. Populasi dan sampel dalam penelitian ini adalah guru pendidikan jasmani dan siswa SMAN Banda Aceh yang mewakili setiap sekolah yang duduk kelas XI. Proses pembuatan alat ukur keefektifan pembelajaran guru pendidikan jasmani meliputi empat tahapan yaitu: (1) Pemilihan butir-butir (item pool) (2) Pemilihan butir (screning of item pool (3) Penyusunan Skala (counstruction of scales) (4) Metode kuisoner. Data yang telah dikumpulkan kemudian dianalisis dengan menggunakan kuantitatif. Berdasarkan hasil dari penelitian yang sudah diperoleh berdasarkan analisis dan pembahasan, maka dapat disimpulkan bahwa skala keefektifan pembelajaran guru pendidikan jasmani Kota Banda Aceh yang terdiri dari tujuh dimensi dan sembilan puluh dua item pernyataan merupakan alat ukur yang valid dan memiliki tingkat kesahihan yang sangat tinggi dengan perolehan poin indek skor validitas 0.929, sehingga dapat digunakan untuk mengukur keefektifan pembelajaran guru pendidikan jasmani dan memiliki tingkat kehandalan yang sangat tinggi dengan perolehan poin indek skor reliabilitas 0.985 , sehingga dapat digunakan untuk mengukur keefektifan pembelajaran guru pendidikan jasmani pada Sekolah Menengah Atas Negeri Kota Banda Aceh.
\end{abstract}

\section{Kata Kunci : Alat Ukur, Keefektifan Pembelajaran, Guru Pendidikan Jasmani}

\section{PENDAHULUAN}

Proses belajar mengajar merupakan proses kegiatan interaksi antara dua unsur manusiawi, yakni siswa sebagai pihak yang belajar dan guru sebagai pihak yang mengajar dengan siswa sebagai subjek pokok. Proses interaksi antara siswa dengan guru, dibutuhkan komponen-komponen pendukung seperti, 1) ada tujuan yang ingin dicapai, 2) ada bahan atau pesan yang menjadi isi interaksi, 3) ada pelajar yang aktif mengalami, 4) ada guru yang melaksanakan, 5) ada metode untuk mencapai tujuan, 6) ada situasi yang memungkinkan proses belajar mengajar berjalan dengan baik,7) ada penilaian terhadap hasil interaksi Sardiman, (2001:13-14).

Pada abad 21 ini tugas dan peran guru pendidikan jasmani semakin berat, mengingat makin banyak dan kompleksnya permasalahan pendidikan jasmani yang ditemukan dilapangan. Sebagai contoh, dengan perubahan pandangan psikologis behavioristik ke humanistik di mana setiap siswa adalah unik dan siswa seyogyanya dipandang sebagai manusia seutuhnya Soemosasmito, (1988:16).

Berbagai upaya telah dilakukan oleh pemerintah untuk mengatasi permasalahan dalam poses pembelajaran, seperti peningkatan kualitas guru melalui peningkatan pendidikan guru, sertifikasi dan pelatihan-pelatihan peningkatan pembelajaran sampai kepada pembentukan "Musyawarah Guru Mata Pelajaran (MGMP)". Selain itu pemerintah juga melakukan pemecahan masalah tentang keterbatasan kemampuan guru 
pendidikan jasmani, seperti peningkatan kemampuan tenaga pengajar pendidikan jasmani melalui penetapan mengajar di sekolah sekarang ini harus lulusan strata satu (S1) selain itu penyempurnaan dan penyesuain kurikulum pendidikan jasmani.

Proses belajar mengajar (PBM) pendidikan jasmani di SMA, guru pendidikan jasmani merupakan ujung tombak sebagai agen perubahan dengan masukan (input) siswa dari berbagai lapisan masyarakat dan sekolah SD, SLTP atau MTS yang berbeda, untuk manghasilkan keluaran (output) yang berkualitas. Untuk menjawab permasalahan tersebut, guru harus menjalankan profesinya semaksimal mungkin dan diperlukan kontrol dan evaluasi yang berkelanjutan baik oleh guru pendidIkan jasmani yang bersangkutan, teman sejawat, kepala sekolah, pengawas, siswa dan oleh masyarakat, mengenai peran dan tanggung jawabnya.

Berdasarkan uraian di atas, maka peneliti tertarik mengangkat judul penelitian tentang "Pengembangan Alat Ukur Keefektifan Pembelajaran Guru Pendidikan Jasmani Kota Banda Aceh”.

\section{Tujuan Penelitian}

Tujuan dari penelitian ini adalah untuk mengembangkan alat ukur keefektifan pembelajaran guru pendidikan jasmani pada SMAN Kota Banda Aceh sebagai skala penilaian sehingga dapat digunakan oleh pihak Dinas Pendidikan, Sekolah, Pengawas dan Guru Pendidikan Jasmani secara valid dan reliabel.

\section{KERANGKA TEORITIS}

\section{Pengembangan Alat Ukur}

Alat ukur merupakan alat untuk mengukur suatu objek ukur atau mengumpul data mengenai suatu variabel yang berfungsi untuk mengungkapkan fakta menjadi data Sugiyono, (2012:148) berhubung ada beberapa macam variabel dan banyak metode untuk mengumpulkan data, maka jenis instrumen penelitianya juga banyak. Menurut jenis variabel yang akan diukur secara garis besar instrumen dapat dibedakan menjadi dua jenis yaitu : 1) instrumen untuk mengukur variabel dengan skala nominal dan ordinal (data kualitatif), 2) instrumen untuk mengukur skala interval dan rasio (data kuantitatif).

Berdasakan pendapat diatas maka dapat disimpulkan bahwa pengembangan sebuat instrumen diperlukan suatu objek yang akan diukur atau mengumpulkan data pada suatu varibel yang akan diteliti dan diperlukan langkah-langkah sehingga mendapat alat ukur yang valid dan reliabel.

\section{Validitas dan Reliabilitas Alat Ukur}

\section{Validitas}

Validitas adalah tingkat kehandalan dan kesahihan alat ukur yang digunakan. Instrumen dikatakan valid berarti menunjukkan alat ukur yang dipergunakan untuk mendapatkan data yang valid atau dapat digunakan untuk mengukur apa yang seharusnya di ukur Sugiyono, (2012:168). Lebih lanjut Amir, (2010:11-12) mengemukakan bahwa validitas pada dasarnya adalah kemampuan alat ukur untuk dapat mengukur apa yang seharusnya di ukur, sebuah tes dikatakan valid apabila tes tersebut mampu mengukur secara tepat terhadap apa yang semestinya diukur.

Menurut Anastasi dan Urbina dalam Sugiyono, (2007:23) validitas berhubungan dengan apakah tes mengukur apa yang mesti diukurnya dan seberapa baik dia melakukannya, sedangkan Borg dan Gall dalam Sugiyono, (2007:169) validitas merupakan derajat sejauh mana tes mengukur apa yang ingin diukur. 


\section{Reliabilitas}

Kata reliabilitas berasal dari bahasa inggris yaitu reability yang berasal dari kata reliable yang berarti dapat dipercaya. Kehandalan (reliability) berasal dari kata relialibel yang artinya dapat dipercaya.

Amir, (2010:12) seseorang dikatakan dapat dipercaya apabila seseorang tersebut selalu berbicara konsisten, tidak berubah-ubah subtansi pembicaraanya dari waktu kewaktu, demikian halnya sebuah tes, dikatakan dapat dipercaya apabila tes tersebut memberikan hasil yang sama meskipun digunakan berkali-kali. Selain itu Hagen dalam Sugiyono, (2012:179) mengemukakan bahwa reliabilitas berhubungan dengan akurasi instrumen dalam mengukur apa yang diukur, kecermatan hasil ukur dan seberapa akurat seandanyai dilakukan pengukuran ulang.

\section{Karateristik Guru Pendidikan Jasmani yang Efektif}

Siedentop, (1983:67) mengemukakan 8 strategi untuk pembelajaran yang efektif di dalam kelas dan diruangan olahraga sebagai yaitu: 1) curahkan sejumlah besar prosentase waktu pada isi atau materi, 2) meminimalkan pergantian waktu dalam kegiatan rutin, 3) curahkan prosentase yang tinggi kandungan waktu untuk berlatih, 4) berikan selalu tugas kepada siswa, 5) berilah tugas yang berarti dan seuai dengan kemampuan siswa, 6) periharalah suatu lingkungan belajar yang dapat memberikan dukungan dan disusun dengan baik tapi memperoleh harapan-harapan yang nyata, 7) berilah pelajaran secara halus, penuh semangat, dan 8) anggap siswa memiliki tanggung jawab pada pembelajaran. Selain itu Hamalik, (2002:23) menyatakan bahwa karakteristik guru harus meliputi:1) demokratis, 2) suka bekerja sama, sabar, adil, konsisten, bersifat terbuka, suka menolong, ramah tamah, memiliki bermacam ragam minat, menguasai bahan pelajaran, menaruh minat yang baik terhadap siswa.

Berdasarkan pendapat diatas maka penulis menyimpulkan bahwa seorang guru yang efektif harus memiliki pengetahuan menguasai teoritis tentang pembelajaran dan tingkah laku siswa dalam proses pembelajaran, serta memiliki sikap yang harmonis sehingga memudahkan siswa dalam proses pembelajaran.

\section{METODE PENELITIAN \\ Rancangan Penelitian}

Berdasarkan permasalahan dan tujuan penelitian sebagaimana yang telah peneliti uraikan diatas, maka untuk mencapai tujuan dari penelitian ini diperlukan suatu rancangan penelitian. Nazir (2005:84) mengemukakan pengertian rancangan penelitian adalah semua proses yang diperlukan dalam perencanaan dan pelaksanaan penelitian, dalam penelitiaan ini adalah pengembangan dengan teknik, interviu, Item Pool dan metode Q-Sort.

\section{Tempat dan Waktu Penelitian}

Penelitian ini mengumpulan butir-butir baru dengan proses item pool dan Screening of item pool dan mereduksi butir-butir dengan metode Q-Sort. Item penelitian dilaksanakan mulai bulan Maret sampai dengan bulan Juli yang dilaksanakan pada siswa kelas XI dengan sampel keseluruhan 15\% dari jumlah keseluruhan siswasiswi SMA Negeri Kota Banda Aceh.

\section{Populasi dan Sampel Penelitian}

Populasi dalam penelitian ini adalah siswa kelas XI yang masih aktif dan guru pendidikan jasmani yang ada di Sekolah Menengah Atas Negeri Kota Banda Aceh. 
Tabel Populasi Penelitian

\begin{tabular}{|c|c|c|c|c|}
\hline No & Nama Sekolah & $\begin{array}{c}\text { Jumlah } \\
\text { Siswa }\end{array}$ & $\begin{array}{c}\text { Siswa Kelas } \\
\text { XI }\end{array}$ & $\begin{array}{c}\text { Jumlah } \\
\text { Guru }\end{array}$ \\
\hline 1 & SMA Negeri 1 Banda Aceh & 528 & 187 & 2 \\
\hline 2 & SMA Negeri 2 Banda Aceh & 668 & 239 & 2 \\
\hline 3 & SMA Negeri 3 Banda Aceh & 787 & 267 & 3 \\
\hline 4 & SMA Negeri 4 Banda Aceh & 775 & 270 & 2 \\
\hline 5 & SMA Negeri 5 Banda Aceh & 634 & 218 & 3 \\
\hline 6 & SMA Negeri 6 Banda Aceh & 441 & 163 & 1 \\
\hline 7 & SMA Negeri 7 Banda Aceh & 668 & 196 & 2 \\
\hline 8 & SMA Negeri 8 Banda Aceh & 709 & 245 & 2 \\
\hline 9 & SMA Negeri 9 Banda Aceh & 499 & 168 & 2 \\
\hline 10 & SMA Negeri 10 Banda Aceh & 287 & 80 & 2 \\
\hline 11 & SMA Negeri 11 Banda Aceh & 441 & 162 & 1 \\
\hline 12 & SMA Negeri 12 Banda Aceh & 532 & 193 & 2 \\
\hline 13 & SMA Negeri 13 Banda Aceh & 165 & 47 & 1 \\
\hline 14 & SMA Negeri 14 Banda Aceh & 116 & 43 & 1 \\
\hline 15 & SMA Negeri 15 Banda Aceh & 174 & 59 & - \\
\hline 16 & SMA Negeri 16 Banda Aceh & 204 & 90 & 1 \\
\hline & Jumlah & 7598 & 2626 & 27 \\
\hline
\end{tabular}

Sumber KTU Disdikpora Kota Banda Aceh

\section{Teknik Pengumpulan Data}

Proses pengembangan alat ukur keefektifan pembelajaran guru pendidikan jasmani dilakukan sebagaimana yang dikemukanan oleh Mutohir, (1986:92) dengan melakukan empat langkah, yaitu: (1) pengumpulan butir (item pool), (2) pemilihan butir-butir (screening of item pool), (3) penyusunan skala (contruction of scales), dan (4) metode kuesioner.

\section{Teknik Analisis Data}

Data yang telah dikumpulkan selanjutnya dikatagorikan dan dianalisis baik secara kulitatif maupun kuantitatif. Data kualitatif digunakan agar dapat lebih menjelaskan permasalahan yang dibahas secara naratif, sedangkan data kuantitatif dianalisis dengan menggunakan teknik-teknik stastistik.

\section{PEMBAHASAN DAN HASIL PENELITIAN Hasil Penelitian \\ 1. Validitas}

Uji validitas merupakan suatu ukuran yang menunjukkan tingkat kehandalan atau keabsahan suatu alat ukur Arikunto, (1995: 63-69 dalam Ridwan, 2010:109). Validitas digunakan untuk mengetahui kelayakan butir-butir dalam satu daftar konstruk pernyataan dalam mendefinisikan suatu variabel Nugroho, (2005:67). Hasil perhitungan validitas butir dengan menggunakan program Statistical Package for Social Sciense, (SPSS 18.0) kesahihan butir didasarkan pada ketentuan diatas 0,30 berdasarkan pendapat Sugiyono, (2012:16) bahwa tingkat kesahihan suatu alat ukur berada diatas 0,30 sehingga instrumen tersebut dikatakan valid, proses uji coba alat ukur keefektifan pembelajaran guru pendidikan jasmani dilakukan pada sampel sebanyak 385 siswa pada sekolah Menengah Atas Negeri Banda Aceh. 


\section{Reliabilitas Alat Ukur}

Pengujian reliabilitas dengan menggunakan rumus Alpha Cronbach, tujuan dari pengujian reliabilitas adalah untuk mengtahui stabilitas internal jawaban dalam satu faktor, hasil perhitungan koefisien reliabilitasi (kehandalan) dilakukan dengan menggunakan program statistical Package for Social siciences (SPSS 18.0) (Ridwan etal. 2011:143-206) dengan jumlah sampel sebanyak 385 siswa. Hasil uji coba reliabilitas dengan menggunkan formula Space saver menunjukkan, bahwa ke tujuh dimensi memiliki koefisien reliabilitas dengan $\alpha$ antara 0,949 sampai sampai 0,985 dengan demikian alat ukur tersebut akan memberikan hasil pengukuran yang handal atau dapat dipercaya. Rangkuman koefisien reliabilitas alat ukur keefektifan pembelajaran guru pendidikan jasmani pada SMAN se-Kota Banda Aceh dapat dilihat pada tabel di bawah ini:

Tabel Rangkuman Reliabilitas Coefficien $(\mathrm{n}=\mathbf{3 8 5})$

\begin{tabular}{|l|c|c|c|c|c|c|c|}
\hline \multicolumn{1}{|c|}{ Dimensi } & $\begin{array}{c}\text { Pengetahua } \\
\text { n }\end{array}$ & $\begin{array}{c}\text { KeadiI } \\
\text { lan }\end{array}$ & Minat & $\begin{array}{c}\text { Kesaba } \\
\text { ran }\end{array}$ & $\begin{array}{c}\text { Kepemi } \\
\text { mpinan }\end{array}$ & $\begin{array}{c}\text { Sema } \\
\text { ngat }\end{array}$ & $\begin{array}{c}\text { Keteram } \\
\text { pilan }\end{array}$ \\
\hline Mean & 54,8104 & 38,4130 & 30,7169 & 38,4805 & 52,4208 & 24,1610 & 79,1506 \\
\hline Variance & 77,477 & 34,811 & 26,016 & 35,443 & 65,005 & 15,568 & 165,389 \\
\hline Std bev & 8,80210 & 5,90007 & 5,10059 & 5,95340 & 806.255 & 3,94560 & 12,86035 \\
\hline N.offariabel & 16 & 11 & 9 & 11 & 15 & 7 & 23 \\
\hline Case & 385 & 385 & 385 & 385 & 385 & 385 & 385 \\
\hline$R_{n}$ Alpha & 0,977 & 0,965 & 0956 & 0,965 & 0,969 & 0,949 & 0,985 \\
\hline table & 0,105 & 0,105 & 0,105 & 0,105 & 0,105 & 0,105 & 0,105 \\
\hline Status & Andal & Andal & Andal & Andal & Andal & Andal & Andal \\
\hline
\end{tabular}

Berdasarkan hasil pengolahan data diatas, dari 92 item pernyataan ternyata semua sahih, sehingga alat ukur dalam penelitian ini terdiri dari 92 item, butir valid diatas 0.30 . Sedangkan uji reliabilitas dengan menggunkan formula space saver menunjukkan bahwa ke tujuh dimensi tersebut memiliki koeffisien reliabiltas dengan $\alpha 0,949$ sampai dengan 0,985 dengan demikian berarti ke tujuh dimensi memenuhi persyaratan pengujian yang berarti bahwa alat ukur tersebut akan memberikan hasil yang dapat dipercaya.

Setelah diadakan uji coba pada 385 siswa SMA Negeri Banda Aceh diperoleh 92 item pernyataan dengan memiliki tingkat validitas dan reliabilitas yang tinggi. Hasil uji coba alat ukur keefektifan pembelajaran guru pendidikan jasmani dengan sampel 385 siswa SMA Negeri Banda Aceh dapat digunakan secara valid dan reliabel.

\section{Analisis Faktor}

Analisis faktor dapat digunakan untuk menguji hipotesis-hipotesis mengenai eksistensi konstruk-konstruk atau untuk mencari konstruk dalam variabel-variabel. Menurut Suyanto, (1988:234) analisis faktor adalah kajian tentang kesaling tergantungan antara variabel-variabel, dengan tujuan untuk menemukan himpunan variabel-variabel baru, yang lebih sedikit jumlahnya dari pada variabel semula, dan menunjukkan yang mana di antara variabel-variabel semula itu yang merupakan faktorfaktor persekutuan. Menurut Gorsuch, (1983:2) tujuan penggunaan analisis faktor adalah meringkas saling hubungan antar variabel-variabel yang ada, tetapi dengan arti yang tepat, sebagai suatu penolong dalam membuat sejumlah pengertian.

Menurut Norusis, (1993:52) ada empat langkah dasar untuk melaksanakan analisis faktor, yaitu (1) menghitung semua matrix korelasi untuk setiap variabel, (2) 
melakukan ekstraksi faktor, (3) melakukan rotasi, dan (4) memberi nama pada setiap faktor.

Uji KMO and Bartlett's test dilakukan untuk mengetahui apakah variabel dan sampel dapat dianalisi lebih lanjut atau tidak, adapun hasil uji KMO and Berttlett's Test 0,975 dengan signifikan 0.000 karena angka tersebut sudah diatas 0.300 dan signifikanya jauh di bawa $0.030(0.000<0.030)$ maka variabel dan sampel yang ada dapat dinalisis lebih lanjut, supaya lebih jelas output hasil KMO and Bartle's test dapat dilihat dalam tabel berikut ini.

Tabel Hasil uji KMO and Bartlett's Test

\begin{tabular}{|c|c|c|}
\hline & \multirow{2}{*}{$\begin{array}{l}, 975 \\
63572,311\end{array}$} \\
\hline \multirow{3}{*}{ Bartlett's Test of Sphericity } & $\begin{array}{l}\text { Kaiser-Meyer-Olkin Measure of Sampling Adequacy. } \\
\text { Bartlett's Test of Sphericity Approx. Chi-Square }\end{array}$ & \\
\hline & Df & \multirow{2}{*}{$\begin{array}{l}4186 \\
, 000\end{array}$} \\
\hline & & \\
\hline
\end{tabular}

\section{a. Uji Anti-Image}

Uji Anti-Image dilakukan untuk menentukan variabel atau faktor mana saja yang layak digunakan dalam analisi lanjutan. Adapun hasil Anti -Image Corelation ternyata dari tujuh dimensi yang terdiri dari sembilan puluh dua item pernyataan tersebut masuk dalam analisis lebih lanjut diantaranya,1) dimensi pengetahuan guru ,2) dimensi keadilan guru, 3) dimensi minat, 4) dimensi kesabaran guru, 5) dimensi kepemimpinan guru, 6) dimensi semangat guru,dan 7) dimensi keterampilan guru untuk lebih jelas output hasil uji Anti-Image Correlation dapat diliha pada tabel.

Tabel Hasil Uji Anti-Image Matrices dengan $\mathbf{r}_{\text {tabel }}(\mathbf{0 . 3 0 0 )}$

\begin{tabular}{|l|l|c|c|}
\hline No & \multicolumn{1}{|c|}{ Dimensi } & \multirow{2}{*}{$\mathrm{r}_{\text {hitung }}$} & Status Faktor \\
\cline { 1 - 2 } \multicolumn{2}{|l|}{ Anti Image Corelation } & & \\
\hline 1. & Pengetahuan & 0,947 & Masuk \\
\hline 2. & Keadilan & 0,959 & Masuk \\
\hline 3. & Minat & 0,969 & Masuk \\
\hline 4. & Kesabaran & 0,955 & Masuk \\
\hline 5. & Kepemimpinan & 0,971 & Masuk \\
\hline 6. & Semangat & 0,967 & Masuk \\
\hline 7. & Keterampilan & 0,940 & Masuk \\
\hline
\end{tabular}

Berdasarkan tabel diatas maka diketahui bahwa nilai Measure of Sampling Adequacy (MSA) untuk masing-masing variabel adalah (D1) 0,947, (D2) 0,959, (D3) 0,969, (D4) 0,955, (D5) 0,971, (D6) 0,967 dan 0,940 (D7); berdasarkan teori, variabel tersebut layak untuk dianalisi adalah nilai MSA lebih dari 0,30, dari semua data analisi ternyata semua dimensi yang terdiri dari sembilan puluh dua item soal semuanya masuk karena nilai MSA lebih besar dari 0,30. Jadi tidak ada lagi dimensi atau item butir soal yang dikeluarkan.

\section{b. Uji Communalities}

Uji Communalities pada dasarnya adalah jumlah varians (bisa dalam persentase) dari satu item mula-mula yang bisa dijelaskan oleh faktor yang ada, untuk item nomor, (1) angka extraction 0,760 hal ini berarti sekitar 76.000 persen varian dari item pernyataan satu bisa dijelaskan oleh faktor yang terbentuk. Untuk item pernyataan nomor, (2) angka ektraction adalah 0,890 hal ini berarti sekitar 89.000 persen varian dari item 2 bisa dijelaskan oleh item yang terbentuk, demikian seterusnya untuk item pernyataan yang lainya, dengan ketentuan bahwa semakin besar comunalities sebuah 
item, berarti semakin erat hubunganya dengan faktor yang terbentuk, untuk lebih jelas lihat output hasil uji comunalities dapat dilihat pada lampiran 15 halaman 138.

c. Uji Total Explained Variance

Total hasil diperoleh dari tabel explained variance diperoleh bahwa hanya tujuh dimensi yang terbentuk, 1 sampai 7 dimensi, angka extraction sums of squared loading diatas 980 sampai dengan 66,983, namun untuk faktor kedelapan sampai dengan sembilan puluh dua angka extraction sums of squared loadings dibawah 980 sehingga proses faktoring terhenti pada 7 dimensi saja untuk lebih jelas output hasil uji total explained variance dapat dilihat pada lampiran 16 halaman 140

\section{d. Uji Faktor Matrix}

Setelah diketahui bahwa tujuh dimensi adalah jumlah yang paling optimal, maka hasil tabel faktor matrik menunjukkan distribusi ke sembilan puluh dua item pernyataan tersebut adalah faktor loadings, yang menunjukan besar korelasi antara suatu item pernyataan dengan dimensi $1,2,3,4,5,6$ dan 7 , proes penentuan item pernyataan yang mana akan kefaktor mana, dilakukan dengan faktor perbandingan besar korelasi pada setiap baris, untuk lebih jelas output hasil uji faktor matrix dan rotasi matrix dapat dilihat pada lampiran 17 halaman 142.

\section{e. Faktor RotationMatrix}

Nilai-nilai yang diperoleh dari korelasi berdasarkan nilai analisis faktor, terlihat dengan jelas bahwa muatan faktor dari 92 item yang terdiri dari 7 dimensi dan masingmasing item bermuatan secara signifikan pada faktor yang ditargetkan untuk diukur. Tampak dimensi dalam skala keefektifan pembelajaran guru pendidikan jasmani saling berkorelasi satu sama lain, walaupun secara analisis masing-masing dimensi nampak jelas memngukur dimensi keefektifan pembelajarn guru pendidikan jasmani yang harus diukur, adapun faktor Rotation matrix. Lampiran 18 halaman 144.

\section{f. Faktor Corelation Matrix}

Nilai-nilai yang diperoleh dari korelasi berdasarkan nilai analisis faktor, terlihat dengan jelas bahwa muatan faktor dari 92 item yang terdiri dari 7 dimensi dan masingmasing item bermuatan secara signifikan pada faktor yang ditargetkan untuk diukur. Tampak dimensi dalam skala keefektifan pembelajaran guru pendidikan jasmani saling berkorelasi satu sama lain, walaupun secara analisis masing-masing dimensin nampak jelas mengukur dimensi keefektifan pembelajaran guru pendidikan jasmani yang harus diukur, adapun hasil faktor corelation matrix dapat dilihat pada Tabel.

Tabel Hasil Faktor Corelation Matrix

\begin{tabular}{|c|c|c|c|c|c|c|c|}
\hline Dimensi & 1 & 2 & 3 & 4 & 5 & 6 & 7 \\
\hline 1 & 1,000 &, 966 &, 971 &, 971 &, 976 &, 971 &, 985 \\
2 &, 966 & 1.000 &, 964 &, 971 &, 968 &, 964 &, 972 \\
3 &, 971 &, 964 & 1.000 &, 956 &, 970 &, 965 &, 976 \\
4 &, 971 &, 971 &, 956 & 1.000 &, 965 &, 966 &, 971 \\
5 &, 976 &, 968 &, 970 &, 965 & 1.000 &, 966 &, 980 \\
6 &, 971 &, 964 &, 965 &, 966 &, 966 & 1.000 &, 973 \\
7 &, 985 &, 972 &, 976 &, 971 &, 980 &, 973 & 1.000 \\
\hline
\end{tabular}

Nilai-nilai yang diperoleh dari korelasi berdasarkan nilai analisi faktor, terlihat dengan jelas bahwa muatan faktor dari 92 item pernyataan yang terdiri dari 7 dimensi dan masing-masing item bermuatan secara signifikan pada faktor yang ditargetkan untuk diukur. Lebih jelas dimensi dalam skala keefektifan pembelajaran guru pendidikan jasmani saling berkorelasi satu sama lain, walaupun secara analisis masing- 
masing dimensi nampak jelas mengukur dimensi keefektifan pembelajaran guru pendidikan jasmani yang harus diukur, adapun faktor Corelation Matrix.

Berdasarkan analisis faktor pada table diatas, maka dapat dilihat faktor keefektifan guru pendidikan jasmani merupakan faktor yang saling berkorelasi (correlated faktors) dengan rentang 0.001 sampai dengan 0.985 .

\section{Dimensi Pengetahuan Guru dalam Pembelajaran}

Berdasarkan hasil validasi dan reliabilitas dan faktor 16 item pernyataan dari dimensi pengetahuan guru yang memenuhi syarat untuk diikut sertakan dalam skala keefektifan pembelajaran guru pendidikan jasmani diantaranya item pernyataan nomor, 1, memahami konsep pendidikan jasmani, 10 memahami pengetahuan pendidikan jasmani, 85 memahami semua cabang olahraga, 82 mampu menjelaskan materi, 57 memahami proses pembelajaran, 65 memahami watak dan kepribadian siwa, 20 memhami perangkat pembelajaran, 91 memahami model-medel pembelajaran, 58 memahami strategi pembalajaran, 2 memahami pengelolaan kelas, 19 memahami penilaian penjdidikan jasmani, 15 memiliki tujuan pembelajaran, 27 memilki ilmu perwasitan, 37 memiliki pengetahuan tentang anatomi, 66 memiliki kompetensi yang bagus.

Dimensi pengetahuan termasuk dimensi pertama dalam keefektifan pembelajaran guru pendidikan jasmani dengan korelasi antara variabel bersih dengan dimensi kesatu dengan rentang yang paling besar terletak pada 0,820 sampai 0,898 .

\section{Dimensi Keadilan Guru dalam Pembelajaran}

Berdasarkan hasil validasi, reliabilitas dan faktor hanya 11 item pernyaan dari dimensi keadilan guru yang memenuhi persyaratan untuk diikutserakan dalam skala keefektifan pembelajaran guru pendidikan jasmani diantaranya item pernyataan nomor, 41 tidak pilih kasih, 90 memberi penilian secara objektif, 11 memberi nilai sesuai dengan kemampuan, 7 tidak pilih kasih dalam semua hal saat pembelajaran, 64 bersikap adil dalam proses pembelajaran, 44 bertanggung jawab dalam proses pembelajaran, 40 tidak membedakan siswa dalam pembelajaran pendidikan jasmani, 75 mampu membuat alokasi waktu yang sesuai, 47 menjadi contoh teladan dalam pembelajaran pendidikan jasmani, 54 menilai melalui teknik-teknik yang sesuai dengan pendidikan jasmani, 13 tidak memandang menang kalah dalam pembelajaran pendidikan jasmani.

Dimensi keadilan termasuk dimensi kedua dalam keefektifan pembelajaran guru pendidikan jasmani dengan korelasi antar variabel bersih dengan faktor kedua yang paling besar pada rentang 0,701 sampai 0,832 .

\section{Dimensi Minat Siswa dalam Pembelajaran}

Berdasarkan hasil validasi, reliabilitas dan faktor hanya 9 item pernyataan dari dimensi minat siswa yang memenuhi persyaratan untuk diikutsertakan dalam skala keefektifan pembelajaran guru pendidikan jasmani diantaranya item pernyataan nomor, 28 memiliki motivasi yang tinggi dalam pembelajaran penjas, 43 memiliki kepedulian terhadap siswa, 78 mampu membuat pembelajaran penjas lebih menarik, 34 memiliki penampilan yang menarik, 48 menyenangkan siswa dalam pembelajaran, 76 murah senyum dalam pembelajaran, 31 mampu memotivasi siswa, 62 mampu memodivikasi peraturan penjas, 79 mampu memodivikasi alat dengan baik.

Dimensi minat termasuk dimensi ketiga dalam keefektifan pembelajaran guru pendidikan jasmani dengan korelasi antar variabel bersih dengan faktor kedua yang paling besar terletak pada rentang 0,831 sampai 0,900 . 


\section{Dimensi Kesabaran Guru dalam Pembelajaran}

Berdasarkan hasil validitas, reliabilitas dan faktor hanya 11 item pernyataan dari dimensi kesabaran guru yang memenuhi persyaratan untuk diikutsertakan dalam skala keefektifan pembelajaran guru pendidikan jasmani diantaranya item pernyataan nomor, 14 memiliki kesabaran dalam praktek, 59 tidak emosi dalam pembelajaran, 63 sabar dalam proses pembelajaran, 23 tidak menggunakan kekerasan dalam pembelajaran pendidikan jasmani, 17 membuat siswa nyaman dalam pembelajaran, 74 tidak bosan mengajar walaupun ada siswa yang tidak paham, 29 tidak berbicara kasar dalam pembelajaran, 22 tidak egois saat pembelajaran, 60 tidak mencela apa bila ada siswa yang belum mengerti, 92 memberikan kesempatan kepada siswa untuk bertanya, dan 25 tidak cepat marah dalam pembelajaran.

Dimensi kesabaran termasuk dimensi keempat dalam keefektifan pembelajaran guru pendidikan jasmani dengan korelasi antara variabel bersih dengan dimensi ke empat terletak pada rentang 0,825 sampai 0,929.

\section{Dimensi Kepemimpinan Guru dalam Pembelajaran}

Berdasarkan hasil validasi, reliabilitas dan faktor hanya 13 item pernyataan dari dimensi kepemimpinan guru yang memenuhi syarat untuk diikut sertakan dalam skala keefektifan guru pendidikan jasmani diantaranya item pernyataan nomor, 32 mengambil keputusan tegas jika ada siwa yang melakuka kesalahan, 88 memiliki disiplin waktu dalam pembelajaran, 70 memiliki ketegasan dalam pembelajaran, 80 tidak kejam tapi tegas dalam pembelajaran, 73 memiliki karakter yang baik, 67 memiliki rasa tanggung jawab dalam pembelajaran, 26 memiliki sikap bijak dalam pembelajaran, 61 dapat memberi pengarahan yang baik terhadap siswa, 86 selalu hadir dalam pembelajaran, 5 memiliki sikap kerjasama, 9 tidak memiliki sikap sombong dalam pembelajaran, 38 memiliki sikap toleransi terhadap siswa, 45 memiliki sikap yang adil, 55 mendengar keluhan yang dihadapi siswa, 35 memahami manajemen penjas dengan baik.

Dimensi kepemimpinan termasuk dimensi kelima dalam keefektifan pembelajaran guru pendidikan jasmani dengan korelasi antara variabel bersih dengan faktor kelima yang paling besar terletak pada rentang 0,548 sampai 0,813 .

\section{Dimensi Semangat Guru dalam Pembelajaran}

Berdasarkan hasil validitas, reliabilitas dan faktor hanya 7 item pernyataan dari dimensi semangat guru yang memenuhi syarat untuk diikutsertakan dalam skala keefektifan pembelajaran guru pendidikan jasmani diantaranya item pernyataan nomor, 39 mampu memberikan motivasi dalam pembelajaran, 21 tidak telad saat pembelajaran, 6 tidak kaku dalam pembelajaran, 16 memiliki inovasi baru dalam pembelajaran penjas, 53 mampu membuat rasa percaya diri pada siswa, 89 menghargai setiap usaha siswa dalam pembelajaran, 81 membuat suasana nyaman dalam pembelajaran.

Dimensi semangat termasuk dimensi keenam dalam keefektifan pembelajaran guru pendidikan jasmani dengan korelasi antara variabel bersih dengan variabel ke enam terletak pada rentang 0,835 sampai 0,915 .

\section{Dimensi Keterampilan Guru dalam Pembelajaran}

Berdasarkan hasil validitas, reliabilitas dan faktor hanya 23 item pernyataan dari dimensi keterampilan guru yang memenuhi syarat untuk diikutsertakan dalam skala keefektifan pembelajaran guru pendidikan jasmani diantaranya item pernyataan nomor, 50 mampu mempraktekkan semua materi dengan baik, 83 mampu mengajar sesuai dengan konsep pendidikan jasmani, 87 mampu memberi arahan kepada siswa saat mempraktekkan sebuah tiori, 52 memiliki suara yang jelas dalam pembelajaran pendidikan jasmani, 42 mampu memberi contoh yang baik, 24 memahami akan gerak 
dalam pendidikan jasmani, 33 memiliki keterampilan dalan olahraga, 84 mampu membuat wacana atau memutar video yang berkaitan dengan olahraga, 30 mampu menguasai kelas dengan baik,36 memiliki pendidikan yang sesuai, 51 dapat memberi penguatan dalam pembelajaran pendidikan jasmani, 69 dapat mempraktekkan tahapantahap dari awal sampai akhir, 4 selalu mencari informasi baru tentang olahraga, 71 mampu menjelaskan materi dengan detail, 77 mampu berinteraksi dengan baik, 3 mampu menguasai siswa saat pembelajaran pendidikan jasmani , 56 memahami gerak yang terkandung dalam pendidikan jasmani, 72 memiliki skil yang baik, 49 dapat mengarahkan semua konsep pembelajaran pendidikan jasmani, 68 mampu melatih siswa dalam kegiatan ekstrakurikuler, 18 menyampaikan materi sesuai dengan kemampuan siswa, 8 selalu mencari pengetahuan yang baru tentang olahraga dan 46 mampu menguasai materi sebelum diajarkan.

Dimensi semangat termasuk dimensi ketujuh dalam keefektifan pembelajaran guru pendidikan jasmani dengan korelasi antara variabel bersih dengan dimensi ke tujuh yang paling besar terletak pada rentang 0,790 sampai dengan 0,909.

\section{Pembahasan Hasil Penelitian}

Dalam proses pengembangan alat ukur keefektifan pembelajaran guru pendidikan jasmani Sekolah Menengah Atas Negeri Kota Banda Aceh ini melalui beberapa tahapan dalam pengumpulan item-item baru dengan langkah-langkah sebagai berikut: pada tahap pertama, (1) proses wawancara, pada tahap kedua, (2) proses grup nominal dan pada tahap ketiga, (3) grup Q-sort, setelah tiga tahapan tersebut selesai maka akan dapat item-item alat ukur keefektifan pembelajaran guru pendidikan jasmani yang akan dikembangkan dan diujicoba, kemudian hasil dianalisis dengan pengujian validitas, reliabilitas dan analisi faktor. Hasil pengujian validitas, reliabilitas dan analisi faktor keefektifan pembelajaran guru pendidikan jasmani akan dijelaskan sebagai berikut:

\section{Validitas}

Berdasarkan hasil pengujian data pada bab hasil penelitian, maka memperoleh hasil 92 item butir pernyataan yang tergabung dalam tujuh dimensi keefektifan pembelajaran guru pendidikan jasmani ternyata memiliki tingkat validitas yang sangat tinggi dengan skor 0,929 hal ini mengacu pada kriteria yang dikemukan oleh Morehouse, Stull dan Bergemen dalam Sugiyono, (2012:172-173) bahwa $000- \pm 200$ derajat validitas sangat rendah, 200- \pm 400 derajat validitas rendah, $400 \pm 600$ validitas sedang, $600 \pm 800$ derajat validitas tinggi dan $800 \pm 1000$ derajat validitas sangat tinggi, disamping itu juga diperoleh nilai validitas lebih kecil dari 0,30 item yang memiliki tingkat validitas paling kecil adalah item no 45 yaitu, 0,548 terdapat pada dimensi kepemimpinan guru dalam pembelajaran pendidikan jasmani sedangkan item yang tingkat validitas paling besar terdapat pada item 17 yaitu 0,929 terdapat pada dimensi kesabaran guru dalam pembelajaran pendidikan jasmani. Ketujuh dimensi keefektifan pembelajaran guru pendidikan jasmani memiliki tingkat validitas sangat tinggi.

\section{Reliabilitas}

Berdasarkan hasil pengujian reliabilitas alat ukur keefektifan pembelajaran guru pendidikan jasmani dari tujuh dimensi alat ukur keefektifan pembelajaran guru pendidikan jasmani ternyata memiliki tingkat reliabilitas yang sangat tinggi, hal ini dapat kita lihat dengan diperoleh harga $r_{\text {hitung }}$ sebesar 0,940 sampai dengan 0,971 Sedangkan $\alpha$ disyaratkan lebih besar dari 0,300 hal ini mengacu pada keriteria yang dikemukankan Moerehouse, Stull dan Bargemen dalam Sugiyono bahwa. 000- \pm .200 derajat reliabilitas sangat rendah, 200- \pm 400 reliabilitas derajat rendah, 400- \pm 600 
derajat reliabilitas sedang, 600- \pm 800 derajat reliabilitas derajat tinggi dan 800- \pm 1000 derajat reliabilitas derajat sangat tinggi. Dimensi yang memiliki derajat reliabilitas paling kecil terdapat pada dimensi semangat 0,949 sedangkan dimensi yang memiliki tingkat reliabilitas paling tinggi terdapat pada keterampilan guru yaitu 0,985 .

Secara keseluruhan dimensi keefektifan pembelajaran guru pendidikan jasmani pada SMA Negeri Banda Aceh yang terkelompok dalam tujuh dimensi mimiliki tingkat validitas sangat tinggi serta tinggkat reliabilitas sangat tinggi yang dapat dijadikan salah satu skala keefektifan pembelajaran guru pendidikan jasmani. Rentang validitas yang sedang serta memiliki tingkat reliabilitas yang sangat tinggi dianggap wajar, karena proses tahapan pengembangan alat ukur keefektifan pembelajaran guru pendidikan jasmani benar-benar dilakukan dengan melibatkan siswa dan guru pendidikan jasmani langsung. Hasil persentase sumbangan konstruk keefektifan pembelajaran guru pendidikan jasmani, jelas bahwa sumbangan paling kecil diberikan oleh dimensi ke enam semangat guru 7\% sedangkan dimensi ke tujuh memberikan sumbangan yang paling besar yaitu 23\%. Bila semua dimensi diurutkan berdasarkan pengembangan alat ukur keefektifan pembelajaran guru pendidikan jasmani secara lengkat dari yang paling rendah sampai ke yang paling tinggi yaitu: (1) dimensi semangat guru sebesar 7\%, (2) dimensi minat siswa sebesar 9\%, (3) dimensi keadilan guru sebesar $11 \%$, (4) dimensi kesabaran 11\%,(5) dimensi kepemimpinan guru sebesar 15\%, (6) Dimensi pengetahuan guru sebesar 16\% dan (7) Dimensi keterampilan guru sebesar 23\%.

\section{Analisis Faktor}

Berdasarkan hasil uji KMO and bartlett's test dilakukan untuk mengetahui apakah variabel dan sampel yang ada dapat dianalisis lebih lanjut atau tidak, adapun hasil uji KMO and Bartlett's test adalah 0,975 dengan signifikan 0,000. Oleh karena itu angka tersebut sudah diatas 0,300 dan signifikan jauh dibawah $0.030(0,00<0,030)$ maka variabel dan sampel yang ada dapat dianalisis lebih lanjut.

Uji anti-image Matrices atau anti image Corelation dilakukan untuk menentukan variabel atau dimensi mana saja yang layak digunakan dalam analisis lanjutan. Adapun hasil anti-image corelation ternyata ada tujuh dimensi yang terdiri dari sembilan puluh dua butir item tersebut masuk untuk dianalisis lanjutan diantaranya dimensi,1) Dimensi pengetahuan guru, 2) Dimensi keadilan guru, 3) Dimensi minat guru, 4) Dimensi kesabaran siswa, 5) Dimensi kepemimpinan guru, 6) Dimensi semangat guru, 7) Dimensi keterampilan guru.

Berdasarkan hasil analisis faktor maka penulis menyimpulkan bahwa dimensi yang mencerminkan keefektifan pembelajaran guru pendidikan jasmani yang diikutsertakan dalam skala sebagai berikut.

\section{a. Dimensi Pengetahuan Guru dalam Pembelajaran}

Berdasarkan hasil pengujian validitas, reliabilitas dan analisi faktor hanya 16 item butir pernyataan dari dimensi pengetahuan yang memenuhi persyaratan untuk diikut sertakan dalam skala keefektifan pembelajaran guru pendidikan jasmani. Adapun skala tersebut yaitu: memahami konsep pendidikan jasmani, memahami pengetahuan pendidikan jasmani, memahami semua cabang olahraga, mampu menjelaskan materi, memahami proses pembelajaran, memahami watak dan kepribadian siwa, memahami perangkat pembelajaran pendidikan jasmani, memahami model-medel pembelajaran pendidikan jasmani, memahami strategi pembalajaran pendidikan jasmani, memahami pengelolaan kelas, memahami penilaian pendidikan jasmani, memiliki tujuan pembelajaran pendidikan jasmani, memilki ilmu perwasitan, memiliki pengetahuan tentang anatomi, memiliki kompetensi yang bagus. 
Dimensi pengetahuan termasuk dalam dimensi pertama dalam keefektifan pembelajaran guru pendidikan jasmani dengan korelasi antara variabel bersih dengan dimensi ke satu paling besar terletak pada rentang 0,947.

\section{b. Dimensi Kedilan Guru dalam Pembelajaran}

Berdasarkan hasil pengujian validitas, reliabilitas dan faktor ada 11 item butir pernyataan dari dimensi keadilan guru yang memenuhi syarat untuk diikut sertakan dalam skala keefektifan pembelajaran guru pendidikan jasmani, adapun skal tersebut yaitu tidak pilih kasih, memberi penilian secara objektif, memberi nilai sesuai dengan kemampuan, tidak pilih kasih dalam semua hal saat pembelajaran, bersikap adil dalam proses pembelajaran, bertanggung jawab dalam proses pembelajaran, tidak membedakan siswa dalam pembelajaran pendidikan jasmani, mampu membuat alokasi waktu yang sesuai, menjadi contoh teladan dalam pembelajaran, menilai melalui teknik-teknik pendidikan jasmani yang sesuai, tidak memandang menang kalah dalam pembelajaran pendidikan jasmani. Dimensi keadilan termasuk dalam dimensi kedu dalam kefektifan pembelajaran guru pendidikan jasmani dengan korelasi antar variabel bersih dengan dimensi ke dua yang paling besar terletak pada rentang 0,959.

\section{c. Dimensi Minat Siswa dalam Pembelajaran}

Berdasarkan hasil pengujian validitas, reliabilitas dan faktor ada 9 item pernyataan dari dimensi minat siswa yang memenuhi syarat untuk diikut sertakan dalam skala keefektifan pembelajaran guru pendidikan jasmani, ada pun ska tersebut yaitu, memiliki motivasi yang tinggi dalam pembelajaran pendidikan jasmani, memiliki kepedulian terhadap siswa, mampu membuat pembelajaran pendidikan jasmani lebih menarik, memiliki penampilan yang menarik, menyenangkan siswa dalam pembelajaran, murah senyum dalam pembelajaran, mampu memotivasi siswa, mampu memodivikasi peraturan pendidikan jasmani, mampu memodivikasi alat dengan baik.

Dimensi minat termasuk dimensi ke tiga dalam keefektifan pembelajaran guru pendidikan jasmani dengan korelasi antar variabel bersih dengn dimensi ketiga paling besar terletak pada rentang 0,965 .

\section{d. Dimensi Kesabaran}

Berdasarkan hasil pengujian validitas, reliabilitas dan faktor ada 11 item pernyataan dimensi kesabaran yang layak diikutsertakan dalam skala alat ukur keefektifan pembelajaran guru pendidikana jasmani, adapun skal tersebut yaitu, memiliki kesabaran dalam praktek, tidak emosi dalam pembelajaran, sabar dalam proses pembelajaran, tidak menggunakan kekerasan dalam pembelajara, membuat siswa nyaman dalam pembelajaran, tidak bosan mengajar walaupun ada siswa yang tidak paham, tidak berbicara kasar dalam pembelajaran, tidak egois saat pembelajaran, tidak mencela apa bila ada siswa yang belum mengerti, memberikan kesempatan kepada siswa untuk bertanya, dan tidak cepat marah dalam pembelajaran.

Dimensi kesabaran termasuk dimensi ke empat dalam alat ukur keefektifan pembelajaran guru pendidikan jasmani dengan korelasi antar variabel bersih dengan dimensi keempat yang paling besar terletak pada rentang 0,955 .

\section{e. Dimensi Kepemimpinan Guru dalam Pembelajaran}

Berdasarkan hasil pengujian validitas, reliabilitas dan faktor hanya 15 item pernyataan dari faktor kepemimpinan guru yang memenuhi syarat untuk diikut sertakan dalam skala alat ukur keefektifan pembelajaran guru pendidikan jasmani, adapun skala tersebut yaitu, mengambil keputusan tegas jika ada siwa yang melakukan kesalahan, memiliki disiplin waktu dalam pembelajaran, memiliki ketegasan dalam pembelajaran, tidak kejam tapi tegas dalam pembelajaran pendidikan jasmani, memiliki karakter yang baik, memiliki rasa tanggung jawab dalam pembelajaran, memiliki sikap bijak dalam 
pembelajaran, dapat memberi pengarahan yang baik terhadap siswa, selalu hadir dalam pembelajaran, memiliki sikap kerjasama, tidak memiliki sikap sombong dalam pembelajaran, memiliki sikap toleransi terhadap siswa memiliki sikap yang adil, mendengar keluhan yang dihadapi siswa, memahami manajemen pendidikan jasmani dengan baik.

Dimensi kepemimpinan termasuk dimensi kelima dalam keefektifan pembelajaran guru pendidikan jasmani dengan korelasi antara variabel bersih dengan variabel kelima yang paling besar terletak pada rentang 0,971 .

\section{f. Dimensi Semangat Guru dalam Pembelajaran}

Berdasarkan hasil pengujian validitas, reliabilitas dan faktor hanya 7 item pernyataan yang memenuhi syarat termasuk untuk diikutsertakan dalam skala keefektifan pembelajaran guru pendidikan jasmani, adapun skla tersebut yaitu, mampu memberikan motivasi dalam pembelajaran pendidikan jasmani, tidak telad saat pembelajaran pendidikan jasmani, tidak kaku dalam pembelajaran pendidikan jasmani, memiliki inovasi baru dalam pembelajaran pendidikan jasmani, mampu membuat rasa percaya diri pada siswa, menghargai setiap usaha siswa dalam pembelajaran pendidikan jasmani, membuat suasana nyaman dalam pembelajaran pendidikan jasmani.

Dimensi semangat termasuk dimensi ke enam dalam pembelajaran guru pendidikan jasmani dengan korelasi antar variabel bersih dengan dimenssi ke enam yang paling besar terletak pada rentang 0,967.

\section{g. Dimensi Keterampilan Guru dalam Pembelajaran}

Berdasarkan hasil pengujian validitas, reliabilitas dan faktor hanya 23 item pernyataan butir dari dimensi keterampilan yang memenuhi syarat untuk diikutsertakan dalam skala keefektifan pembelajaran guru pendidikan jasmani, adapun skala tersebut yaitu, mampu mempraktekkan semua materi dengan baik, mampu mengajar sesuai dengan konsep pendidikan jasmani, mampu memberi arahan kepada siswa saat mempraktekkan sebuah tiori, memiliki suara yang jelas dalam pembelajaran pendidikan jasmani, mampu memberi contoh yang baik, memahami akan gerak dalam pendidikan jasmani, memiliki keterampilan dalan olahraga, mampu membuat wacana atau memutar vidio yang berkaitan dengan olahraga, mampu menguasai kelas dengan baik, memiliki pendidikan yang sesuai, dapat memberi penguatan dalam pembelajaran pendidikan jasmani, dapat mempraktekkan tahapan-tahanp dari awal sampai akhir, selalu mencari informasi baru tentang olahraga, mampu menjelaskan materi dengan detail, mampu berinteraksi dengan baik, mampu menguasai siswa saat pembelajaran pendidikan jasmani, memahami gerak yang terkandung dalam pendidikan jasmani, memiliki skil yang baik, dapat mengarahkan semua konsep pembelajaran pendidikan jasmani, mampu melatih siswa dalam kegiatan ekstrakurikuler, menyampaikan materi sesua dengan kemampuan siswa, selalu mencari pengetahuan yang baru tentang olahraga dan mampu menguasai materi sebelum diajarkan.

Dimensi keterampilan guru dimensi ketujuh dalam keefektifan pembelajaran guru pendidikan jasmani dengan korelasi antar variabel bersih dengan dimensi ke tiga yang paling besar terletak pada rentang 0,940 .

\section{KESIMPULAN}

Berdasarkan hasil yang diperoleh dari penelitian yang sudah dibahas dalam bagian analisis dan pembahasan maka dapat disimpulkan sebagai berikut: Bedasarkan skala keefektifan pembelajaran guru pendidikan jasmani yang terdiri dari 7 dimensi dan 92 item pernyataan yang dapat diikut sertakan dalam skala memiliki tingkat kesahihan yang sangat tinggi dengan perolehan poin indek skor validitas 0,929 sehingga dapat 
digunakan untuk mengukur keefektifan pembelajaran guru pendidikan jasmani dan memiliki tingkat kehandalan yang sangat tinggi dengan perolehan poin indek skor reliabilitas 0,985 sehingga dapat digunakan untuk mengukur keefektifan pembelajaran guru pendidikan jasmani pada Sekolah Menengah Atas Negeri Kota Banda Aceh.

\section{DAFTAR PUSTAKA}

Amir, Nyak, (2004). Pengembangan Alat Ukur Kecemasan Olahraga. Disertasi Doktor pada PPs UNESA Surabaya, tidak diterbitkan.

, (2006). Pembelajaran Penjas. Syiah Kuala Banda Aceh: University Press , (2010). Pengukuran dan evaluasi Kinerja Olahraga Suatu Pendekatan Praktis. Syiah Kuala Banda Aceh: University Press.

Arikunto S, (1996). Prosedur Penelitian Suatu Pendekatan Praktis. Jakarta: Bina Aksara , (2010). Prosedur Penelitian Suatu Pendekatan Praktek: Rineka Cipta

Gorsuch, Richard L, (1983). Factor Analysis. Hillsdale: Lawrence Erlbaum Associates Publisher.

Hamalik, ( 2002). Konsep dasar Pembelajaran. Bandung :Alfabeta , (1990). Profil Guru. Bandung: Tarsito

Mutohir, T. C, (1987). The Development And Examination Of Student Evaluation Of Teaching Effectiveness In an Indonesia Higher Education Setting. Tesis Australia Macquarie University

Nazir, Moh. (2005). Metode Penelitian. Jakarta: Ghalia Indonesia. Sujoko, Efferin dkk. 2004. Metode Penelitian untuk Akuntansi. Jawa Timur

Agung Nugroho, (2005). Strategi Jitu Memilih Metode Statistic Penelitian Dengan. SPSS, Andi Yogyakarta, Yogyakarta

Ridwan,et al, (2011). cara Mudah Belajara statistical Package for Social Sciences, ( SPSS 17.0) dan Aplikasi Statistik Penelitian. Bandung: Alfabeta.

Sardiman, (2001:13-14

Siedentop, D (1983). Developing Teaching Skill in Physical Education .Second edution.Ohio:Mayfield Publihing Company company, pp. 41-50.

Soemosasmito,S, (1998). Dasa, proses dan Efektivitas Belajar Mengajar Pendidikan Jasman. Jakarta: PPLPTK Dirjen Dikti Depdikbud, pp.119-130.

Sugiyono, (2012). Metode Penelitian Kombinasi. Bandung: Alfabeta

Suyanto, (1988). Metode Statistika Multivariat. Jakarta: Departemen Pendidikan dan Kebudayaan. 